\title{
Retraction Note: An osteotomy anterolateral approach for lateral tibial plateau fractures merged with relatively simple and intact posterolateral corner displacement
}

De-peng Meng ${ }^{\dagger}$, Tian-wen $\mathrm{Ye}^{\dagger}$ and Ai-min Chen ${ }^{*}$

\section{Retraction}

The Publisher and Editor regretfully retract this article [1] because the peer-review process was inappropriately influenced and compromised. As a result, the scientific integrity of the article cannot be guaranteed. A systematic and detailed investigation suggests that a third party was involved in supplying fabricated details of potential peer reviewers for a large number of manuscripts submitted to different journals. In accordance with recommendations from COPE we have retracted all affected published articles, including this one. It was not possible to determine beyond doubt that the authors of this particular article were aware of any third party attempts to manipulate peer review of their manuscript.

Received: 4 March 2015 Accepted: 4 March 2015

Published online: 26 March 2015

\section{Reference}

1. Meng D, Ye T, Chen A. An osteotomy anterolateral approach for lateral tibial plateau fractures merged with relatively simple and intact posterolateral corner displacement. J Orthop Surg Res. 2014;9:26.

\footnotetext{
* Correspondence: aiminchen@aliyun.com

${ }^{\dagger}$ Equal contributors

Department of Orthopedic Surgery, Changzheng Hospital, The Second Military Medical University, 415 Fengyang Road, Huangpu District, Shanghai 200003, China
}

\section{Submit your next manuscript to BioMed Central and take full advantage of: \\ - Convenient online submission \\ - Thorough peer review \\ - No space constraints or color figure charges \\ - Immediate publication on acceptance \\ - Inclusion in PubMed, CAS, Scopus and Google Scholar \\ - Research which is freely available for redistribution}

Submit your manuscript at www.biomedcentral.com/submit

() Biomed Central

\section{Biomed Central}

(c) 2015 Meng et al.; licensee BioMed Central. This is an Open Access article distributed under the terms of the Creative Commons Attribution License (http://creativecommons.org/licenses/by/4.0), which permits unrestricted use, distribution, and reproduction in any medium, provided the original work is properly credited. The Creative Commons Public Domain Dedication waiver (http://creativecommons.org/publicdomain/zero/1.0/) applies to the data made available in this article, unless otherwise stated. 